\title{
Development of Cyclic Y-MSH Analogues with Selective hMC3R Agonist and hMC3R/hMC5R Antagonist Activities
}

\author{
Alexander V. Mayorov, Minying Cai, Kevin B. Chandler, Ravil R. Petrov, April R. Van Scoy, \\ Zerui Yu, Dustin K. Tanaka, Dev Trivedi, and Victor J. Hruby \\ Department of Chemistry, University of Arizona, Tucson, Arizona 85721
}

\section{Abstract}

A series of cyclic lactam analogues of $\gamma$-MSH $\left(\mathrm{H}_{-} \mathrm{Tyr}^{1}{ }^{1} \mathrm{Val}^{2}-\mathrm{Met}^{3}-\mathrm{Gly}^{4}-\mathrm{His}^{5}-\mathrm{Phe}^{6}-\mathrm{Arg}^{7}-\mathrm{Trp}^{8}\right.$ Asp $\left.-\mathrm{Arg}^{10}{ }^{10} \mathrm{Phe}^{11}-\mathrm{Gly}^{12}-\mathrm{OH}\right)$ with a bulky hydrophobic residue in the direct proximity to the pharmacophore (Xaa-р-Phe/p-Nal(2')-Arg-Trp) were designed and synthesized by solid-phase methods. A variety of amino acids with a broad range of hydrophobic/hydrophilic properties was introduced in position 5 to further explore their complementary role in receptor selectivity. Biological evaluation of these peptides revealed several analogues with potent hMC3R agonist and hMC3R/ hMC5R antagonist activities, and good receptor selectivity. Analogue 4, c[Nle-Arg-o-Phe-Arg-TrpGlu] $-\mathrm{NH}_{2}$, was found to be a very potent and selective hMC3R agonist $\left(\mathrm{EC}_{50}=1.2 \mathrm{nM}, 112 \%\right.$ act $)$. In addition, analogue 13, c[Nle-Val-D-Nal(2')-Arg-Trp-Glu]-NH ${ }_{2}$, was identified as an hMC3R/ $\mathrm{hMC} 5 \mathrm{R}$ antagonist with the best selectivity against the $\mathrm{hMC} 4 \mathrm{R}$ in this series $\left(\mathrm{pA}_{2}(\mathrm{hMC} 3 \mathrm{R})=8.4\right.$; $\left.\mathrm{pA}_{2}(\mathrm{hMC} 5 \mathrm{R})=8.7\right)$. These results indicate the significance of steric factors in melanocortin receptor selectivity and suggest that introduction of bulky residues in the direct proximity to the melanocortin pharmacophore is an effective approach to design of novel hMC3R and hMC5R selective ligands.

\section{Introduction}

The natural melanotropin peptides include $\alpha-, \beta$-, and $\gamma$-melanocyte-stimulating hormones (MSH) and adrenocorticotropin (ACTH). All of these hormones are derived by posttranslational processing of the pro-opiomelanocortin (POMC) gene transcript, ${ }^{1}$ and each of them possess a central "core" sequence His-Phe-Arg-Trp, which is essential for their agonist biological activity. 2,3 It has been discovered that the melanocortin receptors (hMCR) and their ligands control a surprisingly large number of multifaceted biological actions including skin pigmentation, ${ }^{4-6}$ erectile function, ${ }^{7-11}$ blood pressure and heart rate, ${ }^{12}$ control of feeding behavior and energy homeostasis, ${ }^{13-19}$ modulation of aggressive/defensive behavior, ${ }^{20}$ and mediation of pain. ${ }^{21}$ To date, five melanocortin receptor subtypes with different patterns of tissue expression in the brain and in the periphery have been cloned and characterized. ${ }^{22}$ The $\mathrm{hMC} 1 \mathrm{R}$ is mainly expressed in melanocytes and leukocytes and has been implicated to play a role in skin pigmentation and inflammatory responses and control of the immune system, 5,6 , 23,24 whereas the hMC $2 \mathrm{R}$ is expressed in the adrenal cortex and mediates steroidogenesis and other effects. ${ }^{25,26}$ Of particular interest for therapeutical applications are the hMC $3 \mathrm{R}$ and the hMC4R, which have been implicated to play complementary roles in weight control. ${ }^{13-19}$ Extensive studies have been carried out toward highly selective and potent agonists at the $\mathrm{hMC} 4 \mathrm{R}$ as potential therapeutics for treating obesity, while selective hMC4R antagonists have been targeted as promising drug candidates for treating anorexia and cancer- and HIV-related

* To whom correspondence should be addressed: Phone: 520 621-6332. Fax: 520 621-8407. E-mail: hruby @u.arizona.edu..

Supporting Information Available: ${ }^{1}$ H NMR spectra of peptide analogues 1-16 in DMSO- $d_{6} /$ acetonitrile- $d_{3}$, a listing of chemical shifts and coupling constants, and results from biological activity assays. This material is available free of charge via the Internet at http:// pubs.acs.org. 
weight loss. $5,6,27,28$ The hMC3R has recently been suggested to be physiologically involved in the control of energy partitioning and body weight, ${ }^{29}$ although the broad scope of the physiological functions of this receptor has not been fully investigated. Therefore, selective ligands at this receptor will be important tools in exploring the entire array of biological functions of the hMC3R, and in conjunction with an hMC4R agonist, they might provide a novel approach to the treatment of obesity, anorexia, weight loss, and related disorders. Finally, the hMC5R, found in a variety of peripheral tissues, plays a role in regulating exocrine gland function $^{30}$ and coordinating central and peripheral signals for aggression. 20

Among the natural melanocyte-stimulating hormones, $\alpha$-MSH and $\beta$-MSH show little selectivity for any specific receptor subtype, in contrast to $\gamma$-MSH, which exhibits significant hMC3R selectivity. ${ }^{31,32}$ Our laboratories have previously reported several linear $\gamma$-MSH analogues with substantially improved potency and hMC3R selectivity, out of which $\mathrm{D}-\operatorname{Trp}^{8}$ $\gamma$-MSH ${ }^{31}$ and Ac-NDP- $\gamma$-MSH-NH ${ }_{2}{ }^{32}$ were the most promising leads. Bednarek et al. ${ }^{33}$ have reported several 21-membered or a larger cyclic lactam analogues of $\alpha$-MSH and $\gamma$-MSH, which were found to be potent and hMC4R-selective agonists. At the same time, Kavarana et al. ${ }^{34}$ have found that enhancing the hydrophobic properties of the cyclic $\alpha$-MSH analogues combined with the increased ring size resulted in improved hMC3R selectivity. Furthermore, Grieco et al. ${ }^{35}$ have shown that the certain dihedrally constrained amino acid substitutions at the position 6 of Ac-Nle ${ }^{4}-\mathrm{c}\left[\mathrm{Asp}^{5}{ }_{\text {, }}-\mathrm{Phe}^{7}, \mathrm{Lys}^{10}\right] \alpha-\mathrm{MSH}(4-10)-\mathrm{NH}_{2}$ (MT-II) led to potent and highly hMC3R and hMC4R selective antagonists. Cai et al. ${ }^{36}$ have shown that steric interactions in $\chi$-space of $\beta$-modified proline- 6 analogues of MT-II resulted in enhanced hMC5R selectivity. In addition, various substitutions (e.g. Gln, Asn, Lys, Arg, Ala, Phe, etc.) at the position 6 of $\alpha$-MSH have been reported to produce analogues with improved hMC4R selectivity. 37,38

On the basis of these observations, we have designed a series of novel cyclic $\gamma$-MSH analogues with the following general sequence: c[Nle-Xaa-p-Phe/p-Nal(2')-Arg-Trp-Glu]-NH $\mathrm{N}_{2}$, which features the amide bond between the $\varepsilon$-carboxyl group of the $\mathrm{C}$-terminal glutamic acid amide residue and the $\alpha$-amino group of the $\mathrm{N}$-terminal norleucine residue as the global constrain. We introduced a bulky hydrophobic residue $\left(\mathrm{Nle}^{4}\right)$ in the close proximity to the pharmacophore (Xaa-D-Phe/D-Nal(2')-Arg-Trp) to investigate the impact of steric hindrance on receptor selectivity. Also, a variety of amino acids with a broad range of hydrophobic/hydrophilic properties was placed in the position 5 to further explore their complementary role in receptor selectivity.

\section{Molecular Modeling and Peptide Design}

In our efforts to obtain highly potent and selective melanotropin peptides, we have designed and synthesized a series of novel cyclic $\gamma$-MSH analogues (Figure 1). The peptide sequences of the cyclic $\gamma$-MSH analogues and their physicochemical properties are listed in Table 1. In the design process we performed computational experiments using hybrid Monte Carlo/lowfrequency mode (MCMM/LMCS) ${ }^{39}$ simulations with the OPLS-AA force field 40 and the GB/ SA continuum dielectric water solvent model ${ }^{41}$ implemented in the Macromodel 8.1 software package (Schrödinger, Portland, OR) to identify the three-dimensional structures of the melanotropin peptides that would resemble the secondary structures of the nonselective super agonist MT-II and the hMC3R/hMC4R antagonist SHU9119 (Figures 2 and 3), which were earlier reported by our laboratories. ${ }^{42}$ The detailed computational procedures are described in the Experimental Section. As evident from the Figures 2 and 3, the secondary structures of the peptides in this series feature a rigid $\beta$-loop, which fits well with the NMR structures of MTII and SHU9119 and varies little with position 5 substitutions (Table 2). The rigidity of this $\beta$-loop scaffold in addition to smaller macrocycle (20-membered ring) as compared to MT-II (23-membered ring) may have contributed to the increased receptor selectivity observed in this 
series (vide infra). In addition, Figures 2 and 3 also display hydrophobic interactions between the side chains of $\mathrm{Nle}^{4}$ and $\mathrm{Arg}^{7}$, which may have led to partial steric hindrance of the binding space of $\mathrm{Arg}^{7}$, resulting in further increase in receptor selectivity that would favor the receptor subtypes with larger binding pocket (Figure 4). Negatively charged amino acid (Asp ${ }^{5}$ and $\mathrm{Glu}^{5}$ ) substitutions at position 5 induced intramolecular salt bridge interactions between the side chains of $\mathrm{Xaa}^{5}$ and $\mathrm{Arg}^{7}$ (Figure 5), which were expected to limit the involvement of $\mathrm{Arg}^{7}$ in the receptor-ligand interactions, thus affecting the biological activities of the corresponding analogues. This design approach allowed detailed and systematic evaluation of effects of steric, hydrophobic, and electrostatic factors on ligand-receptor interaction and selectivity in human melanocortin receptors.

\section{Results and Discussion}

Table 3 summarizes the binding affinities and the in vitro biological activities of the peptides under study. In the ${ }_{\mathrm{D}}-\mathrm{Phe}^{6}$ series, analogue $1\left(\mathrm{c}\left[\mathrm{Nle}^{4}-\mathrm{His}^{5}{ }_{-\mathrm{D}}-\mathrm{Phe}^{6}-\mathrm{Arg}^{7}-\mathrm{Trp}^{8}-\mathrm{Glu}^{9}\right]-\mathrm{NH}_{2}\right)$ was found to be inactive at the hMC1R, a full agonist at the hMC $3 \mathrm{R}\left(\mathrm{EC}_{50}=37 \mathrm{nM}\right)$, a weak partial agonist at the hMC4R ( $\mathrm{EC}_{50}=2 \mu \mathrm{M}, 48 \%$ activation), and an antagonist at the hMC5R. When $\mathrm{His}^{5}$ was replaced by $\operatorname{Pro}^{5}$ (analogue 2), there was a considerable loss in binding affinities as well as bioefficacy for all the receptor subtypes, which may be due to the increased rigidity of the 20-membered macrocycle as compared to the 23-membered MT-II-type cyclic lactams, where such substitutions had been found to increase potency and selectivity. 35 Analogue 3 exhibited weak binding affinity and partial agonist activity at the hMC1R, weak partial agonist activity at the hMC3R, no binding affinity and no agonist activity at the hMC4R, and a weak antagonist activity for the hMC5R. Analogue 4, with an $\mathrm{Arg}^{5}$ substitution, demonstrated very potent hMC3R agonist activity $\left(\mathrm{EC}_{50}=1.2 \mathrm{nM}\right)$ and a 150 -fold selectivity against the $\mathrm{hMC} 4 \mathrm{R}$ $\left(\mathrm{EC}_{50}=174 \mathrm{nM}, 63 \%\right.$ activation$)$. This increase in potency is likely to be caused by enhanced electrostatic interaction between the ligand and the receptor. It is interesting to note that this compound exhibits only modest binding potency toward the hMC3R, which could be due to the influence of the steric hindrance of $\mathrm{Nle}^{4}$ on the peptide binding affinity. A similar trend, albeit to a lesser extent, was observed for analogues $\mathbf{1}$ and $\mathbf{5}$. Analogue $\mathbf{4}$ also showed a very weak binding affinity for the hMC1R and a moderate antagonist activity at the hMC5R.

Hydrophobic substitutions at position $5\left(\mathrm{Val}^{5}\right.$, analogue 5 , and $\mathrm{Nle}^{5}$, analogue 6$)$ resulted in no affinity for the hMC1R and weak binding affinity and partial agonist activity for the other receptor subtypes, with the exception of full agonist activity at the hMC3R for analogue 5 and a modest antagonist activity at the hMC5R for analogue $\mathbf{6}$. Negatively charged amino acid substitutions at position $5\left(\mathrm{Asp}^{5}\right.$, analogue 7 , and $\mathrm{Glu}^{5}$, analogue 8) led to a drastic drop in ligand-receptor interactions for all receptor subtypes, which can be attributed to unfavorable electrostatic interactions. Another possible explanation for this loss in binding affinities is the intramolecular salt bridge interactions between the side chains of $\mathrm{Arg}^{7}$ and $\mathrm{Asp}^{5} / \mathrm{Glu}^{5}$ (Figure 5), which would limit the involvement of $\mathrm{Arg}^{7}$ in receptor-ligand interactions. Similar findings were earlier reported by Bednarek et al., 33,43 where replacement of His residue with Glu led to a significant decline in binding affinity.

In the ${ }_{\mathrm{D}}-\mathrm{Nal}\left(2^{\prime}\right)^{6}$ series, analogue $9\left(\mathrm{c}\left[\mathrm{Nle}^{4}-\mathrm{His}^{5}-\mathrm{D}-\mathrm{Nal}\left(2^{\prime}\right)^{6}-\mathrm{Arg}^{7}-\mathrm{Trp}^{8}-\mathrm{Glu}^{9}\right]-\mathrm{NH}_{2}\right)$ exhibited a very potent antagonist activity at the hMC3R and the hMC5R $\left(\mathrm{IC}_{50}=12\right.$ and $2.3 \mathrm{nM}$, respectively), a weak antagonist activity at the $\mathrm{hMC} 4 \mathrm{R}\left(\mathrm{IC}_{50}=100 \mathrm{nM}\right)$, and a complete loss of binding affinity for the hMC1R. Next, $\mathrm{His}^{5}$ was replaced with $\operatorname{Pro}^{5}$ (analogue 10), Gln (analogue 11), $\mathrm{Arg}^{5}$ (analogue 12), $\mathrm{Val}^{5}$ (analogue 13), and $\mathrm{Nle}^{5}$ (analogue 14). Interestingly, binding affinities of these compounds for the hMC3R and the hMC5R were found to be in the nanomolar range (1.4-13 nM), similar to analogue 9. Furthermore, analogues 10-14 also showed antagonistic activity at these two receptor subtypes. At the same time, these analogues exhibited no significant interaction with the hMC1R and weak partial agonist activities at the hMC4R, except for analogue 10, which was determined to be a weak hMC4R antagonist. The 
most selective hMC3R (2400-fold vs hMC1R and 100-fold vs hMC4R) and hMC5R (1800fold vs hMC1R and 80-fold vs hMC4R) antagonist was found to be analogue $\mathbf{1 3}\left(\mathrm{pA}_{2}(\mathrm{hMC} 3 \mathrm{R})\right.$ $\left.=8.4 ; \mathrm{pA}_{2}(\mathrm{hMC} 5 \mathrm{R})=8.7\right)$. The higher degree of receptor-ligand interactions observed in the D-Nal $\left(2^{\prime}\right)^{6}$ series for the hMC3R $\left(\mathrm{IC}_{50}=1.4-13 \mathrm{nM}\right)$ and the $\mathrm{hMC} 5 \mathrm{R}\left(\mathrm{IC}_{50}=1.4-10 \mathrm{nM}\right)$ could be due to increased hydrophobicity of these melanotropin peptides and enhanced aromatic receptor-ligand interactions. It is particularly interesting to note that replacing $\mathrm{His}^{5}$ with a variety of hydrophobic and hydrophilic amino acids has little impact on the hMC3R/hMC5R antagonist activities of the compounds in this series. This clearly indicates that $\mathrm{His}^{5}$ in cyclic analogues of $\alpha-\mathrm{MSH} / \gamma-\mathrm{MSH}$ only has structural importance and most likely is not directly involved in the receptor-ligand interactions critical for agonist or antagonist activities. The significant finding in this study was the pronounced effect of steric hindrance on hMC3R and hMC5R selectivity, which led to the discovery of the novel cyclic peptide antagonist scaffold with good hMC3R/hMC5R selectivity vs the hMC1R (500-2400-fold) and the hMC4R (up to 100-fold) in analogues 9-14. The observation that binding potencies of analogues 9-14 at the hMC5R were not significantly affected by the steric bulk of the residues $\mathrm{Nle}^{4}$ and $\mathrm{Xaa}^{5}$ used in this study was in agreement with our earlier findings that the hMC5R has a low sensitivity for steric factors, probably due to a larger size of the receptor pocket. ${ }^{36}$ Figure 4 illustrates the effects of steric hindrance on the melanocortin receptor selectivity. In addition, an important consequence of steric hindrance from $\mathrm{Nle}^{4}$ in the ${ }_{\mathrm{D}-\mathrm{Nal}}\left(2^{\prime}\right)^{6}$ series is the loss of agonist activity at the hMC5R, which is generally observed in a wide variety of ${ }_{\mathrm{D}} \mathrm{Nal}\left(2^{\prime}\right)^{7}$ analogues of $\alpha$-MSH and ${ }_{\mathrm{D}}-\mathrm{Nal}\left(2^{\prime}\right)^{6}$ analogues of $\gamma$-MSH. ${ }^{33,35,43,44}$ This observation suggests that steric effects can be used as valuable tool in converting agonist properties of melanotropin peptides at the hMC5R to antagonist activities at this receptor. Finally, Asp ${ }^{5}$ and Glu $^{5}$ substitutions (analogues 15 and 16, respectively) resulted in considerable (20-100-fold) decline in binding affinities to the $\mathrm{hMC} 3 \mathrm{R}\left(\mathrm{IC}_{50}=820\right.$ and $\left.135 \mathrm{nM}\right)$ and the $\mathrm{hMC} 5 \mathrm{R}\left(\mathrm{IC}_{50}=220\right.$ and $\left.44 \mathrm{nM}\right)$, while retaining the similar binding affinities to the $\mathrm{hMC} 4 \mathrm{R}\left(\mathrm{IC}_{50}=168\right.$ and $\left.34 \mathrm{nM}\right)$. Overall, this type of position 5 substitution seems to be unfavorable for melanocortin receptor binding. Consistent with the rest of the peptides in this study, analogues $\mathbf{1 5}$ and $\mathbf{1 6}$ were also found to be inactive at the hMC1R.

\section{Summary}

Computer-aided design of $\gamma$-MSH analogues has yielded a novel series of cyclic peptides that feature a rigid $\beta$-loop, which is very similar to the secondary structures of the nonselective superagonist MT-II and the hMC3R/hMC4R antagonist SHU9119. Modeling experiments have also suggested that introduction of a bulky hydrophobic residue in the direct proximity to the melanocortin pharmacophore would result in some steric hindrance of the $\mathrm{Arg}^{7}$ side chain that could potentially affect receptor selectivity. This hypothesis has led to discovery of selective hMC3R agonists and potent hMC3R/hMC5R antagonists with good selectivity against the hMC1R and the hMC4R. Specifically, analogue 4, c[Nle-Arg-o-Phe-Arg-Trp-Glu]$\mathrm{NH}_{2}$, was found to be a very potent and selective $\mathrm{hMC} 3 \mathrm{R}$ agonist $\left(\mathrm{EC}_{50}=1.2 \mathrm{nM}, 112 \%\right.$ act $)$ and analogue 13, c[Nle-Val-p-Nal(2')-Arg-Trp-Glu]- $\mathrm{NH}_{2}$, was identified as an hMC3R/ $\mathrm{hMC5R}$ antagonist with the best selectivity against the $\mathrm{hMC} 4 \mathrm{R}$ in this series $\left(\mathrm{pA}_{2}(\mathrm{hMC} 3 \mathrm{R})=\right.$ 8.4; $\left.\mathrm{pA}_{2}(\mathrm{hMC} 5 \mathrm{R})=8.7\right)$. The unique scaffold described in this study exemplifies the utility of steric effects as the means of discriminating among the melanocortin receptor subtypes. In addition, replacement of $\mathrm{His}^{5}$ with a variety of hydrophobic and hydrophilic amino acids produced several potent hMC3R agonists and $\mathrm{hMC} 3 \mathrm{R} / \mathrm{hMC} 5 \mathrm{R}$ antagonists, which is evidence for the structural but not a functional role of $\mathrm{His}^{5}$ in $\alpha-\mathrm{MSH} / \gamma-\mathrm{MSH}$ analogues. Finally, the selective hMC3R agonist $\mathbf{4}$ and the hMC3R/hMC5R antagonist $\mathbf{1 3}$ described in this study will be useful in elucidating the physiological roles of the hMC $3 \mathrm{R}$ and the hMC4R, particularly in feeding behavior, obesity, and related disorders. 


\section{Experimental Section}

\section{Materials}

$\mathrm{N}^{\alpha}$-Fmoc-amino acids and Rink amide AM (w/Nle) resin were obtained from Chem-Impex International (Wood Dale, IL), except $\mathrm{N}^{\alpha}$-Fmoc-Glu(OAll)-OH, which was purchased from NeoMPS (San Diego, CA), and Cl-HOBt was acquired from Bachem (King of Prussia, PA). The following side chain protecting groups were used: $\operatorname{Asp}\left(\mathrm{O}^{\delta}-t \mathrm{Bu}\right)$; $\mathrm{Glu}\left(\mathrm{O}^{\varepsilon}-t \mathrm{Bu}\right) ; \mathrm{Glu}\left(\mathrm{O}^{\varepsilon_{-}}\right.$ Allyl); Trp-(N $\left.{ }^{\text {in }}-\mathrm{Boc}\right) ; \operatorname{Arg}\left(\mathrm{N}^{\varepsilon}-\mathrm{Pbf}\right) ; \mathrm{His}\left(\mathrm{N}^{\mathrm{im}}-\mathrm{Trt}\right) ; \mathrm{Gln}\left(\mathrm{N}^{\varepsilon}-\mathrm{Trt}\right)$. ACS grade organic solvents were purchased from VWR Scientific (West Chester, PA), and other reagents were obtained from Sigma-Aldrich (St. Louis, MO) and used as commercially available. The polypro-pylene reaction vessels (syringes with frits) ${ }^{45}$ were purchased from Torviq (Niles, MI). The purity of the peptides was checked by analytical reverse-phase HPLC using a Vydac $\mathrm{C}_{18} 218 \mathrm{TP} 104$ column (Western Analytical Products, Murrieta, CA) monitored at 230 and $254 \mathrm{~nm}$ and by thin-layer chromatography (TLC), both performed using two different solvent systems. Analytical thin-layer chromatography (TLC) was carried out on $0.25 \mathrm{~mm}$ glass-backed silica gel $60 \mathrm{~F}_{254}$ plates (EM Science 5715, VWR Scientific). The TLC chromatograms were visualized by UV light and by dipping in potassium permanganate solution followed by heating (hot plate).

\section{Peptide Synthesis}

All peptides in this study were synthesized manually by the $\mathrm{N}^{\alpha}$-Fmoc solid-phase methodology using DIC and Cl-HOBt as the coupling reagents. ${ }^{46,47}$ Rink amide AM (w/Nle) resin (4.0 g, $0.637 \mathrm{mmol} / \mathrm{g}$ ) was placed into a $50 \mathrm{~mL}$ polypropylene syringe with the frit on the bottom and swollen in DMF $(20 \mathrm{~mL})$ for $1 \mathrm{~h}$. The Fmoc protecting group on the Rink linker was removed by $25 \%$ piperidine in DMF $(1 \times 5$ min and $1 \times 15 \mathrm{~min})$. The resin was washed with $\mathrm{DMF}(3 \times$ $15 \mathrm{~mL})$ and then with DCM $(3 \times 15 \mathrm{~mL})$. $\mathrm{N}^{\alpha}$-Fmoc-Glu(OAll)-OH ( 3 equiv) and $\mathrm{Cl}-\mathrm{HOBt}(3$ equiv) were dissolved in $10 \mathrm{~mL}$ of DMF, and then DIC (3 equiv) was added. The coupling mixture was transferred into the syringe with the resin and shaken for $30 \mathrm{~min}$. The resin was washed three times with DMF $(15 \mathrm{~mL})$ and three times with DCM $(15 \mathrm{~mL})$, the unreacted amino groups were capped using acetic anhydride $(2 \mathrm{~mL})$ and pyridine $(2 \mathrm{~mL})$ in DCM $(15$ $\mathrm{mL})$ for $30 \mathrm{~min}$, and the resin was once again washed with DCM $(6 \times 15 \mathrm{~mL})$. The next three amino acids, Trp, Arg, and ${ }_{\mathrm{D}}-\mathrm{Phe}$ or ${ }_{\mathrm{D}}-\mathrm{Nal}\left(2^{\prime}\right)$, were consecutively coupled using the procedure described above, using the Kaiser ninhydrin test to check the extent of coupling. In case of a positive Kaiser test, the coupling was repeated until a negative Kaiser test was obtained. The resulting batch of the resin-bound protected tetrapeptide Fmoc-D-Phe/D-Nal(2')-Arg-Trp-Glu was carefully washed with DMF $(5 \times 15 \mathrm{~mL})$, DCM $(5 \times 15 \mathrm{~mL})$, methanol $(5 \times 15 \mathrm{~mL})$, and diethyl ether $(5 \times 15 \mathrm{~mL})$ and dried under reduced pressure $(16 \mathrm{~h})$. The dry resin was split in 8 equal portions, which were placed in separate $10 \mathrm{~mL}$ fritted polypropylene syringes and swollen with DMF as described above. The same coupling procedure was followed to complete the desired peptide sequences, except chloranil test was used to monitor coupling to proline instead of Kaiser test. The orthogonal allyl ester protection for the side chain of $\mathrm{Glu}^{10}$ was removed with 0.1 equiv of $\mathrm{Pd}\left(\mathrm{PPh}_{3}\right)_{4} / 20$ equiv of $\mathrm{PhSiH}_{3}$ in $\mathrm{DCM}(2 \times 30 \mathrm{~min})$ prior to the peptide cyclization. ${ }^{48}$ The deprotected resin-bound peptide was washed with $10 \%$ DIPEA solution in DCM $(1 \times 5 \mathrm{~mL} \times 10 \mathrm{~min})$, DCM $(6 \times 5 \mathrm{~mL})$, and THF $(1 \times 5 \mathrm{~mL})$. The peptide cyclizations were found to proceed in facile manner with 6 equiv of DIC and 6 equiv of $\mathrm{Cl}$ HOBt in THF (72 h) and were monitored by Kaiser ninhydrin test. Upon completion of cyclization the resin was treated with 5\% solution of sodium diethyldithiocarbamate trihydrate in DMF $(20 \mathrm{~min})$ and then washed with DMF $(5 \times 15 \mathrm{~mL}), \mathrm{DCM}(3 \times 15 \mathrm{~mL})$, methanol $(5 \times$ $15 \mathrm{~mL})$, and diethyl ether $(5 \times 15 \mathrm{~mL})$ and dried under reduced pressure $(16 \mathrm{~h})$. The cyclized peptides were cleaved off the solid support with $82.5 \%$ v/v TFA, $5 \%$ water, $5 \%$ thioanisol, $2.5 \%$ 1,2-ethanedithiol, and $5 \%$ phenol ( $5 \mathrm{~mL}, 3 \mathrm{~h})$, and the crude peptides were precipitated out by the addition of a chilled 3:1 mixture of diethyl ether and petroleum ether $(50 \mathrm{~mL})$ to 
give white precipitates. The resulting peptide suspensions were centrifuged for $10 \mathrm{~min}$ at 6500 $\mathrm{rpm}$, and the liquid was decanted. The crude peptides were washed with diethyl ether $(4 \times 50$ $\mathrm{mL}$ ), and after the final centrifugation, the peptides were dried under vacuum $(2 \mathrm{~h})$. The resulting white residues were dissolved in $2 \mathrm{M}$ acetic acid, and the insoluble impurities were removed by passing the solutions through syringe filters (Gelman Laboratory, Acrodisc $13 \mathrm{~mm}$ syringe filter with $0.45 \mu \mathrm{M}$ PTFE membrane). The clear filtrates were lyophilized, the obtained white powders were dissolved in glacial acetic acid $(1 \mathrm{~mL})$, and the resulting solutions were diluted with water $(4 \mathrm{~mL})$ and passed through a Sephadex G-15 column. Fractions containing the target peptides, as determined by TLC, were combined and lyophilized. Final purification was accomplished by preparative RP-HPLC on a $\mathrm{C}_{18}$-bonded silica column (Vydac $218 \mathrm{TP} 152022,250 \times 22 \mathrm{~mm}, 15-20 \mu \mathrm{m}, 300 \AA$ ) eluted with a linear gradient of $20-80 \%$ acetonitrile in $0.1 \%$ aqueous TFA solution over $50 \mathrm{~min}$ with $10 \mathrm{~mL} / \mathrm{min}$ flow rate. The purified peptides were isolated in 30-35\% overall yield and were $>95 \%$ pure as determined by analytical RP-HPLC. The structures of the pure peptides were confirmed by high-resolution fast atom bombardment (FAB) mass spectrometry and ${ }^{1} \mathrm{H}$ NMR in DMSO- $d_{6} /$ acetonitrile- $d_{3}$.

\section{Biological Activity Assays. Receptor Binding Assay}

Competition binding experiments were carried out using whole HEK293 cells stably expressing human MC1, MC3, MC4, and MC5 receptors. HEK293 cells transfected with hMCRs $^{36,49,50}$ were seeded on 96 -well plates $48 \mathrm{~h}$ before assay (100 000 cells/well). For the assay, the cell culture medium was aspirated and cells were washed twice with a freshly prepared binding buffer containing 100\% minimum essential medium with Earle's salt (MEM, GIBCO), $25 \mathrm{mM}$ HEPES (pH 7.4), 0.2\% bovine serum albumin, $1 \mathrm{mM}$ 1,10-phenanthrolone, $0.5 \mathrm{mg} / \mathrm{L}$ leupeptin, and $200 \mathrm{mg} / \mathrm{L}$ bacitracin. Next, cells were incubated with different concentrations of unlabeled peptide and labeled $\left[{ }^{125} \mathrm{I}\right]-\left[\mathrm{Nle},{ }_{\mathrm{D}}-\mathrm{Phe}{ }^{7}\right]-\alpha-\mathrm{MSH}$ (Perkin-Elmer Life Science, $100000 \mathrm{cpm} /$ well, $0.1386 \mathrm{nM}$ ) for $40 \mathrm{~min}$ at $37^{\circ} \mathrm{C}$. The assay medium was subsequently removed, and each well was washed twice with the binding buffer. The cells were then lysed by the addition of $250 \mu \mathrm{L}$ of $0.1 \mathrm{M} \mathrm{NaOH}$ and $250 \mu \mathrm{L}$ of $1 \%$ Triton X-100. The lysed cells were transferred to $12 \times 75 \mathrm{~mm}$ glass tubes, and the radioactivity was measured by a Wallac 1470 WIZARD Gamma Counter.

\section{Adenylate Cyclase Assay}

HEK 293 cells transfected with human melanocortin receptors 36 were grown to confluence in MEM medium (GIBCO) containing 10\% fetal bovine serum, 100 units/mL penicillin and streptomycin, and $1 \mathrm{mM}$ sodium pyruvate. The cells were seeded on 96 -well plates $48 \mathrm{~h}$ before assay (100 000 cells/well). For the assay, the cell culture medium was removed and the cells were rinsed with $1 \mathrm{~mL}$ of MEM buffer (GIBCO) or with Earle's balanced salt solution (EBSS, GIBCO). An aliquot $(0.4 \mathrm{~mL})$ of the Earle's balanced salt solution was placed in each well along with $5 \mu \mathrm{L} 0.5 \mathrm{mM}$ isobutylmethylxanthine (IBMX) for $1 \mathrm{~min}$ at $37^{\circ} \mathrm{C}$. Next, varying concentration aliquots of melanotropin peptides $(0.1 \mathrm{~mL})$ were added, and the cells were incubated for $3 \mathrm{~min}$ at $37^{\circ} \mathrm{C}$. The reaction was stopped by aspirating the assay buffer and adding $0.15 \mathrm{~mL}$ ice-cold Tris/EDTA buffer to each well. After dislodging the cells with the help of trypsin, the cells were transferred to polypropylene microcentrifuge tubes and placed in a boiling water bath for $15 \mathrm{~min}$. The cell lysate was then centrifuged for $2 \mathrm{~min}$ at $6500 \mathrm{rpm}$, and $50 \mu \mathrm{L}$ of the supernatant was aliquoted into an Eppendorf tube. The total cAMP content was measured by competitive binding assay according to the TRK 432 assay kit instructions (Amersham Corp., Piscataway, NJ). The antagonist properties of the lead compound were evaluated by its ability to competitively displace the MT-II agonist in a dose-dependent manner, at up to $10 \mu \mathrm{M}$. The $\mathrm{pA}_{2}$ values were obtained using the Schild analysis method. ${ }^{51}$ 


\section{Data Analysis}

$\mathrm{IC}_{50}$ and $\mathrm{EC}_{50}$ values represent the mean of two experiments performed in triplicate. $\mathrm{IC}_{50}$ and $\mathrm{EC}_{50}$ estimates and their associated standard errors were determined by fitting the data using a nonlinear least-squares analysis, with the help of GraphPad Prism 4 (GraphPad Software, San Diego, CA).

\section{Computational Procedures}

Molecular modeling experiments employed Macromodel 8.1 equipped with Maestro 5.1 graphical interface (Schrödinger, Portland, OR) installed on a Linux Red Hat 9.0 system. Peptide structures were built into extended structures with standard bond lengths and angles, and they were minimized using the OPLS-AA force field 40 and the Polak-Ribier conjugate gradient (PRCG). Optimizations were converged to a gradient RMSD less that $0.05 \mathrm{~kJ} / \AA \mathrm{mol}$ or continued until a limit of 50000 iterations was reached. Aqueous solution conditions were simulated using the continuum dielectric water solvent model (GB/SA). ${ }^{41}$ Extended cutoff distances were defined at $8 \AA$ for van der Waals, $20 \AA$ for electrostatics, and $4 \AA$ for H-bonds.

Conformational profiles of the cyclic peptides were investigated by the hybrid Monte Carlo/ low-frequency mode (MCMM/LMCS) ${ }^{39}$ procedure as implemented in Macromodel using the energy minimization parameters as described above. MCMM torsional variations and low mode parameters were set up automatically within Maestro graphical user interface. A total of 10000 search steps were performed, and the conformations with energy difference of $50 \mathrm{~kJ} /$ mol from the global minimum were saved. Interatomic dihedral angles were measured for each peptide analogue using the Maestro graphical user interface, and they are described in Table 2 . The superimpositions of peptide structures were performed using the $\alpha$-carbons of the core sequence Xaa-D-Phe/d-Nal(2')-Arg-Trp.

\section{Supplementary Material}

Refer to Web version on PubMed Central for supplementary material.

\section{Acknowledgements}

This research was supported by grants from the U.S. Public Health Service, National Institutes of Health DK-17420 and DA-13449. The opinions expressed are those of the authors and not necessarily those of the USPHS.

\section{References}

1. Pritchard LE, Turnbull AV, White A. Pro-opiomelanocortin processing in the hypothalamus: impact on melanocortin signaling and obesity. J Endocrinol 2002;172:411-421. [PubMed: 11874690]

2. Hruby VJ, Wilkes BC, Hadley ME, Al-Obeidi F, Sawyer TK, Staples DJ, de Vaux AE, Dym O, Castrucci AMF, Hintz MF, Riehem JP, Rao KR. $\alpha$-Melanotropin: The minimal active sequence in the frog skin bioassay. J Med Chem 1987;30:2126-2130. [PubMed: 2822931]

3. Castrucci A-Mde L, Hadley ME, Sawyer TK, Wilkes BC, Al-Obeidi F, Staples DJ, de Vaux AE, Dym O, Hintz MF, Riehm JP, Rao RR, Hruby VJ. $\alpha$-Melanotropin: The minimal active sequence in the lizard skin bioassay. Gen Comput Endocrinol 1989;73:157-163.

4. Hadley, M. E.; Castrucci, A.-M. de L. Melanotropin Mechanisms of Action: Melanosome Movements. In The Melanotropic Peptides. Mechanisms of Action and Biomedical Applications; Hadley, M. E., Ed.; CRC Press: Boca Raton, FL, 1988; Vol. III, pp 15-25.

5. Cone, R. D., Ed. The melanocortin system. Ann NY Acad Sci2003, 994, pp 1-387.

6. Cone, R. D., Ed. The Melanocortin Receptors; Humana Press: Totowa, NJ, 2000.

7. Wessells H, Gralnek D, Dorr R, Hruby VJ, Hadley ME, Levine N. Effect of an $\alpha$-melanocyte stimulating hormone analogue on penile erection and sexual desire in men with organic erectile dysfunction. Urology 2000;56:641-646. [PubMed: 11018622] 
8. Wessells H, Fuciarelli K, Hansen J, Hadley ME, Hruby VJ, Dorr R, Levine N. Synthetic melanotropic peptide initiates erections in men with psychogenic erectile dysfunction: double-blind placebo controlled crossover study. J Urol 1998;160:389-393. [PubMed: 9679884]

9. Bertolini A, Vergoni W, Gessa GL, Ferrari W. Induction of sexual excitement by action of adrenocorticotropic hormone in brain. Nature 1969;221:667-669. [PubMed: 4304587]

10. Bertolini, A.; Vergoni, W.; Gessa, G. L.; Ferrari, W. Erection and Ejaculation: A Central Effect of ACTH-Like Peptides in Mammals. In Sexual Behavior: Pharmacology and Biochemistry; Sandler, M., Gessa, G. L., Eds.; Raven Press: New York, 1975; pp 247-257.

11. Van der Ploeg LHT, Martin WJ, Howard AD, Nargund RP, Austin CP, Guan X, Drisko J, Cashen D, Sebhat I, Patchett AA, Figueroa DJ, DiLella AG, Connolly BM, Weinberg DH, Tan CP, Palyha OC, Pong S-S, MacNeil T, Rosenblum C, Vongs A, Tang R, Yu H, Sailer AW, Fong TM, Huang C, Tota MR, Chang RS, Stearns R, Tamvakopoulos C, Christ G, Drazen DL, Spar BD, Nelson RJ, MacIntyre DE. A role for the melanocortin 4 receptor in sexual function. Proc Natl Acad Sci USA 2002;99:11381-11386. [PubMed: 12172010]

12. Li SJ, Varga K, Archer P, Hruby VJ, Sharma SD, Kesterson RA, Cone RD, Kunos G. Melanocortin antagonists define two distinct pathways of cardiovascular control by $\alpha$ - and $\gamma$-melanocyte stimulating hormones. J Neurosci 1996;16:5182-5188. [PubMed: 8756446]

13. Fan W, Boston BA, Kesterson RA, Hruby VJ, Cone RD. Role of the melanocortinergic neurons in feeding and the Agouti obesity syndrome. Nature 1997;385:165-168. [PubMed: 8990120]

14. Vergoni AV, Poggioloi R, Bertolini A. Corticotropin inhibits food intake in rats. Neuropeptides 1986;7:153-158. [PubMed: 3010169]

15. Vergoni AV, Poggioloi R, Marrama D, Bertolini A. Inhibition of feeding by ACTH-(1-24): Behavioral and pharmacological aspects. Eur J Pharmacol 1990;179:347-355. [PubMed: 2194823]

16. Ramos EJB, Meguid MM, Campos ACL, Coelho JCU. Neuropeptide Y, $\alpha$-melanocyte-stimulating hormone, and monoamines in food intake regulation. Nutrition 2005;21:269-279. [PubMed: 15723758]

17. Yang YK, Harmon CM. Recent developments in our understanding of melanocortin system in the regulation of food intake. Obes Rev 2003;4:239-248. [PubMed: 14649374]

18. Ellacott KLJ, Cone RD. The central melanocortin system and the integration of short- and long-term regulators of energy homeostasis. Recent Prog Horm Res 2004;59:395-408. [PubMed: 14749511]

19. Zimanyi IA, Pelleymounter MA. The role of melanocortin peptides and receptors in regulation of energy balance. Curr Pharm Des 2003;9:627-641. [PubMed: 12570796]

20. Morgan C, Thomas RE, Cone RD. Melanocortin-5 receptor deficiency promotes defensive behavior in male mice. Horm Behav 2004;45:58-63. [PubMed: 14733892]

21. Mogil JS, Wilson SG, Chesler EJ, Rankin AL, Nemmani KVS, Lariviere WR, Groce MK, Wallace MR, Kaplan L, Staud R, Ness TJ, Glover TL, Stankova M, Mayorov AV, Hruby VJ, Grisel JE, Fillingim RB. The melanocortin-1 receptor gene mediates female-specific mechanisms of analgesia in mice and humans. Proc Natl Acad Sci USA 2003;100:4867-4872. [PubMed: 12663858]

22. Mountjoy, K. G. Cloning of the melanocortin receptors. In Melanocortin Receptors; Cone, R. D., Ed.; Humana Press: Totowa, NJ, 2000; pp 209-235.

23. Vaudry, H.; Eberle, A. N., Eds. The melanotropic peptides. Ann NY Acad Sci1993, 680, 1-687

24. Hadley, M. E., Ed. The Melanotropic Peptides. CRC Press: Boca Raton, FL, 1988; Vols. I-III.

25. Gispen WH, Isaacson RL. ACTH-induced excessive grooming in the rat. Pharmacol Ther 1981;12:209-246. [PubMed: 6114501]

26. Gantz I, Fong TM. The melanocortin system. Am J Physiol Endocrinol Metab 2003;284:E468-E474. [PubMed: 12556347]

27. Hruby VJ, Cai M, Grieco P, Han G, Kavarana M, Trivedi D. Exploring the stereostructural requirements of peptide ligands for the melanocortin receptors. Ann NY Acad Sci 2003;994:12-20. [PubMed: 12851293]

28. Holder JR, Haskell-Luevano C. Melanocortin ligands: 30 years of structure-activity relationship (SAR) studies. Med Res Rev 2004;24:325-356. [PubMed: 14994367]

29. Chen AS, Marsh DJ, Trumbauer ME, Frazier EG, Guan X-M, Yu H, Rosenblum CI, Vongs A, Feng Y, Cao LH, Metzger JM, Strack AM, Camacho RE, Mellin TN, Nunes CN, Min W, Fisher J, GopalTruter S, MacIntyre DE, Chen HY, Van der Ploeg LHI. Inactivation of the mouse melanocortin-3 
receptor results in increased fat mass and reduced lean body mass. Nat Genet 2000;26:97-102. [PubMed: 10973258]

30. Chen WB, Kelly MA, Opitz Araya X, Thomas RE, Low MJ, Cone RD. Exocrine gland dysfunction in mc5-r deficient mice: Evidence for coordinated regulation of exocrine gland function by melanocortin peptides. Cell 1997;91:789-798. [PubMed: 9413988]

31. Grieco P, Balse PM, Weinberg D, MacNeil T, Hruby VJ. d-Amino acid scan of $\gamma$-melanocytestimulating hormone: Importance of $\operatorname{Trp}^{8}$ on human MC3 receptor selectivity. J Med Chem 2000;43:4998-5002. [PubMed: 11150170]

32. Cai M, Mayorov AV, Cabello C, Stankova M, Trivedi D, Hruby VJ. Novel 3D pharmacophore of $\alpha-\mathrm{MSH} / \gamma-\mathrm{MSH}$ hybrids leads to selective human MC1R and MC3R analogues. J Med Chem 2005;48:1839-1848. [PubMed: 15771429]

33. Bednarek MA, MacNeil T, Tang R, Kalyani RN, Van der Ploeg LHT, Weinberg DH. Potent and selective peptide agonists of $\alpha$-melanotropin action at human melanocortin receptor 4: Their synthesis and biological evaluation in vitro. Biochem Biophys Res Commun 2001;286:641-645. [PubMed: 11511108]

34. Kavarana MJ, Trivedi D, Cai M, Ying J, Hammer M, Cabello C, Grieco P, Han G, Hruby VJ. Novel cyclic templates of $\alpha$-MSH give highly selective and potent antagonists/agonists for human melanocortin-3/4 receptors. J Med Chem 2002;45:2644-2650. [PubMed: 12036373]

35. Grieco P, Lavecchia A, Cai M, Trivedi D, Weinberg D, MacNeil T, Van der Ploeg LHT, Hruby VJ. Structure-activity studies of the melanocortin peptides: Discovery of potent and selective affinity antagonists for the hMC3 and hMC4 receptors. J Med Chem 2002;45:5287-5294. [PubMed: 12431055]

36. Cai M, Cai C, Mayorov AV, Xiong C, Cabello CM, Soloshonok VA, Swift JR, Trivedi D, Hruby VJ. Biological and conformational study of substituted prolines in MT-II template: Steric effects leading to human MC5 receptor selectivity. J Pept Res 2004;63:116-131. [PubMed: 15009533]

37. Li S-Z, Lee J-H, Lee W, Yoon C-J, Baik J-H, Lim S-K. Type I $\beta$-turn conformation is important for biological activity of the melanocyte-stimulating hormone analogues. Eur J Biochem 1999;265:430 440. [PubMed: 10491201]

38. Nijenhuis WAJ, Kruijtzer JAW, Wanders N, Vrinten DH, Garner KM, Schaaper WMM, Meloen RH, Gispen WH, Liskamp RM, Adana RAH. Discovery and in vivo evaluation of new melanocortin-4 receptor-selective peptides. Peptides 2003;24:271-280. [PubMed: 12668212]

39. Kolossáry I. Guida WCLow-mode conformational search elucidated. Application to C39H80 and flexible docking of 9-dea-zaguanine inhibitors to PNP. J Comput Chem 1999;20:1671.

40. Jorgensen WL, Maxwell DS, Tirado-Rives J. Development and testing of the OPLS all-atom force field on conformational energetics and properties of organic liquids. J Am Chem Soc 1996;118:11225-11235.

41. Still WC, Tempczyk A, Hawlely RC, Hendrickson T. A General treatment of solvation for molecular mechanics. J Am Chem Soc 1990;112:6127-6129.

42. Ying J, Kövér KE, Gu X, Han G, Trivedi DB, Kavarana MJ, Hruby VJ. Solution structures of cyclic melanocortin agonists and antagonists by NMR. Biopolymers 2003;71:696-716. [PubMed: 14991679]

43. Bednarek MA, MacNeil T, Kalyani RN, Tang R, Van der Ploeg LHT, Weinberg DH. Analogues of lactam derivatives of $\alpha$-melanotropin with basic and acidic residues. Biochem Biophys Res Commun 2000;272:23-28. [PubMed: 10872798]

44. Hruby VJ, Lu D, Sharma SD, Castrucci Ade L, Kesterson RA, Al-Obeidi FA, Hadley ME, Cone RD. Cyclic lactam $\alpha$-melanotropin analogues of Ac-Nle ${ }^{4}$-cyclo[ $\left[\mathrm{Asp}^{5}, \mathrm{D}-\mathrm{Phe}^{7}, \mathrm{Lys}^{10}\right]$ - $\alpha$-melanocytestimulating hormone-(4-10)- $\mathrm{NH}_{2}$ with bulky aromatic amino acids at position 7 show high antagonist potency and selectivity at specific melanocortin receptors. J Med Chem 1995;38:3454-3461. [PubMed: 7658432]

45. Krchnak V, Vagner J. Color-monitored solid-phase multiple peptide synthesis under low-pressure continuous-flow conditions. Pept Res 1990;3:182-193. [PubMed: 2134062]

46. Sabatino G, Mulinacci B, Alcaro MC, Chelli M, Rovero P. Papini AMAssessment of new 6-Cl-HOBt based coupling reagents for peptide synthesis. Part 1: Coupling efficiency study. Lett Pept Sci 2003;9 (2-3):119-123. 
47. Di Fenza A. Rovero PAssessment of new 6-Cl-HOBt based coupling reagents for peptide synthesis. Part 2: Racemization studies. Lett Pept Sci 2003;9(2-3):125-129.

48. Thieriet N, Alsina J, Giralt E, Guibé F. Albericio FUse of alloc-amino acids in solid-phase peptide synthesis. Tandem depro-tection-coupling reactions using neutral conditions. Tetrahedron Lett 1997;38:7275-7278.

49. Haskell-Luevano C, Miwa H, Dickinson C, Hruby VJ, Yamada T, Gantz I. Binding and CAMP studies of melanotropin peptides with the cloned human peripheral melanocortin receptor, hMC1R. Biochem Biophys Res Commun 1994;204:1137-1142. [PubMed: 7980588]

50. Gantz I, Miwa H, Konda Y, Shimoto Y, Tashiro T, Watson SJ, Delvalle J, Yamada T. Molecular cloning of a novel melanocortin receptor. J Biol Chem 1993;268:15174-15179. [PubMed: 8392067]

51. Schild HO. pA, a new scale for the measurement of drug antagonism. Br J Pharmacol 1947;2:189206.

52. Abbreviations used for amino acids and designation of peptides follow the rules of the IUPAC-IUB Commission of Biochemical Nomenclature. J Biol Chem 1972;247:977-983. [PubMed: 5010073] Abbreviations: All, allyl; Boc, tert-butyloxycarbonyl; Fmoc, fluo-renylmethoxycarbonyl; t-Bu, tertbutyl; $\mathrm{CH}_{3} \mathrm{CN}$, acetonitrile; $\mathrm{Cl}-\mathrm{HOBt}$, 1-hydroxy-6-chlorobenzotriazole; DCM, dichloromethane; DIEA, diisopropylethylamine; DMF, N,N-dimethylformamide; DIC, diisopropylcarbodiimide; hMCR, human melanocortin receptor; MSH, melanocyte-stimulating hormone; $\mathrm{Nal}\left(2^{\prime}\right), 2^{\prime}$ naphthylalanine; NMR, nuclear magnetic resonance; Pbf, 2,2,4,6,7-pentamethyldihydrobenzofuran-5-sulfonyl; TFA, trifluoroacetic acid; Trt, trityl; SPPS, solid-phase peptide synthesis; RPHPLC, reverse-phase high-performance liquid chromatography; hMC3R, human melanocortin-3 receptor; $\alpha$-MSH, Ac-Ser-Tyr-Ser-Met-Glu-His-Phe-Arg-Trp-Gly-Lys-Pro-Val-NH 2 ; NDP- $\alpha$ MSH, Ac-Ser-Tyr-Ser-Nle-Glu-His-D-Phe-Arg-Trp-Gly-Lys-Pro-Val-NH $2 ; \gamma-\mathrm{MSH}$, H-Tyr-ValMet-Gly-His-Phe-Arg-Trp-Asp-Arg-Phe-Gly-OH 


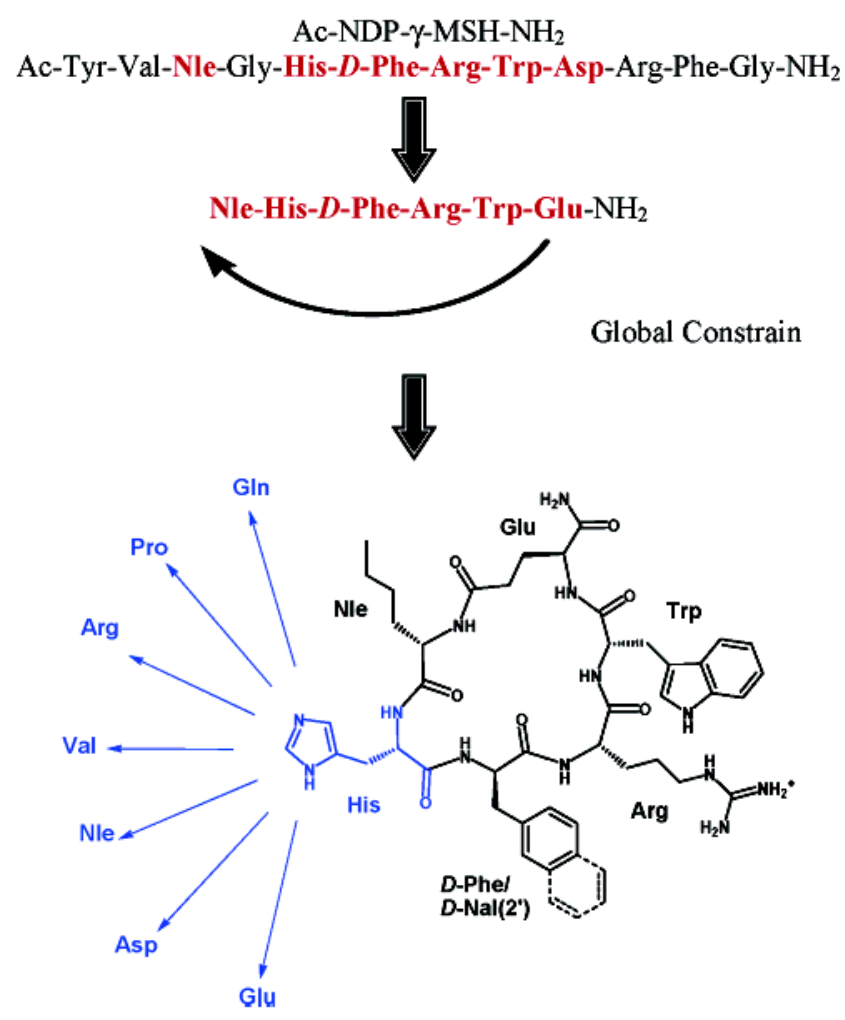

Figure 1.

Design of the novel $\gamma$-MSH-derived cyclic lactam scaffold. 

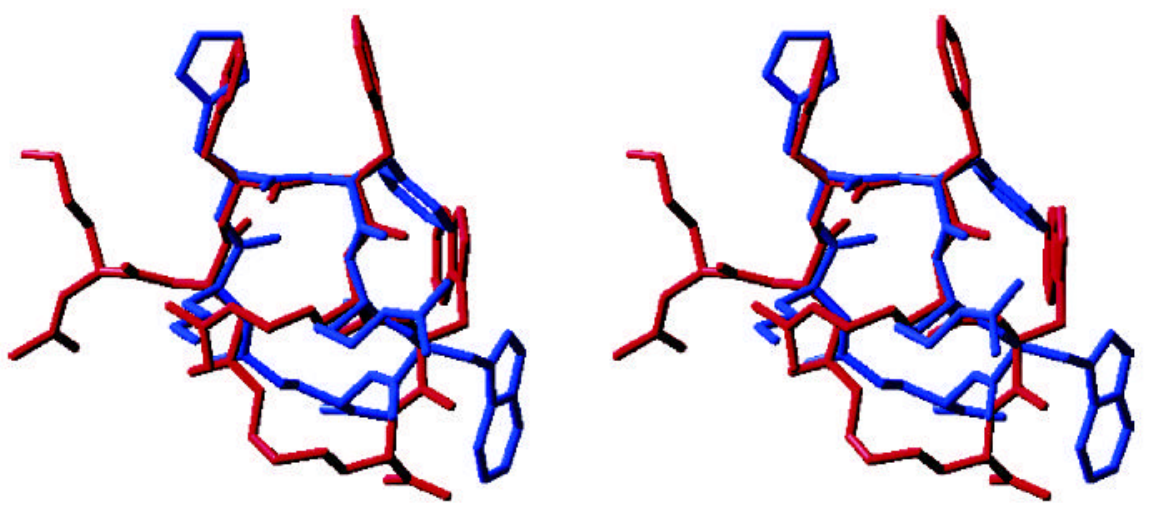

Figure 2.

Stereoview of the superimposed global minimum of analogue 1, c[Nle-His-D-Phe-Arg-TrpGlu]- $\mathrm{NH}_{2}$, obtained by MCMM/LMCS (Monte Carlo multiple minima-low-frequency mode)OPLS-AA simulation with the NMR structure of nonselective superagonist MT-II, Ac-Nle-c [Asp-His-o-Phe-Arg-Trp-Lys]- $\mathrm{NH}_{2}(\mathrm{rmsd}=0.21 \AA$ A $)$. Hydrogens are omitted for clarity. 

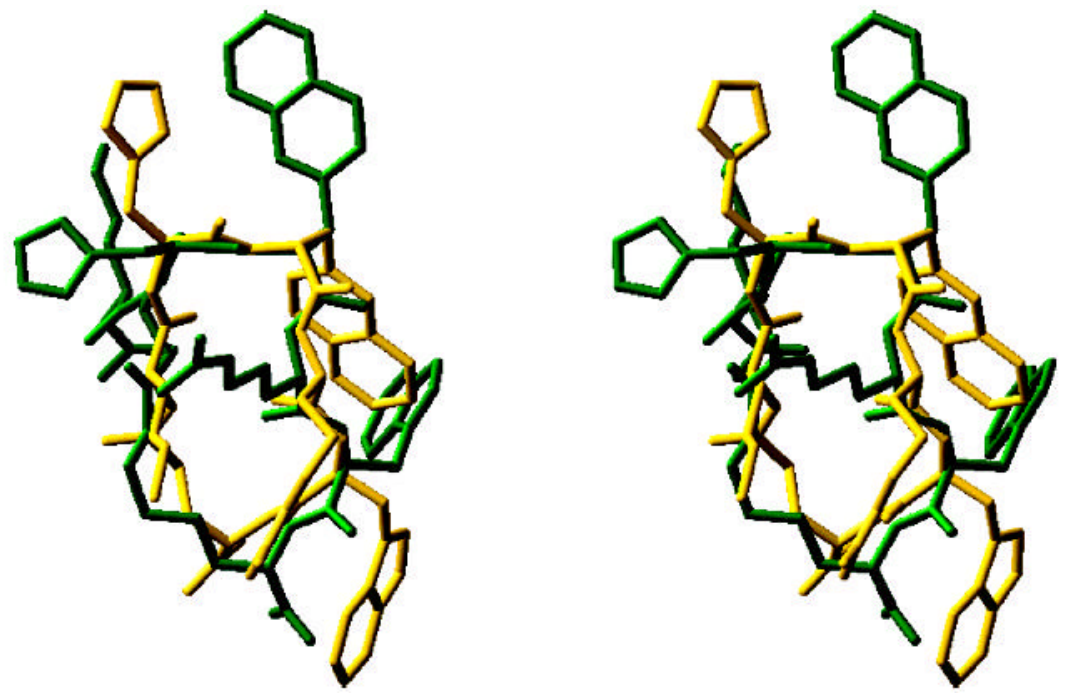

Figure 3.

Stereoview of the superimposed global minimum of analogue 9, c[Nle-His-d-Nal(2')-Arg-TrpGlu]- $\mathrm{NH}_{2}$, obtained by MCMM/LMCS (Monte Carlo multiple minima-low-frequency mode)OPLS-AA simulation with the NMR structure of hMC3R/hMC4R antagonist SHU9119, Ac-

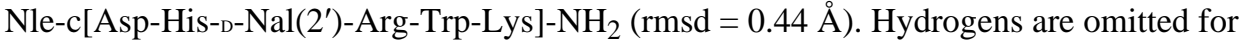
clarity. 

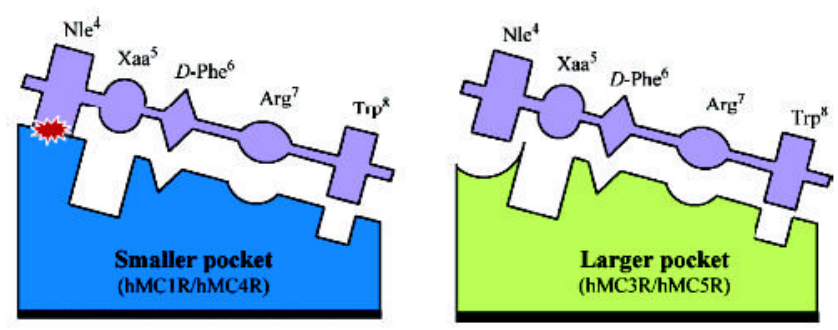

Figure 4.

Influence of steric interference from Nle, ${ }^{4}$ placed in close proximity to the pharmacophore, on the melanocortin receptor selectivity. 

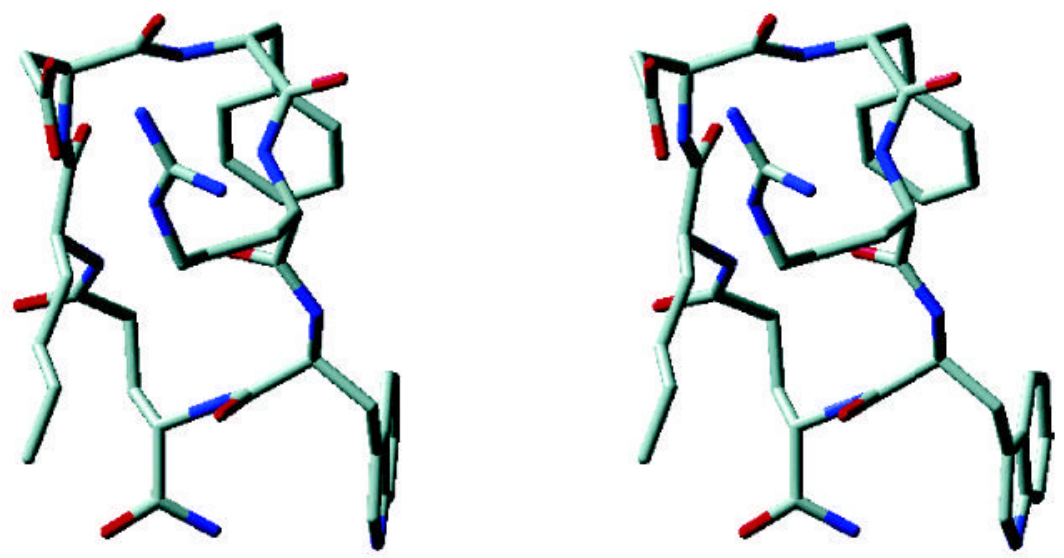

Figure 5.

Stereoview of the global minimum of analogue 7, c[Nle-Asp-o-Phe-Arg-Trp-Glu]-NH $\mathrm{N}_{2}$, obtained by MCMM/LMCS (Monte Carlo multiple minima-low-frequency mode)-OPLS-AA simulation. Hydrogens are omitted for clarity. 


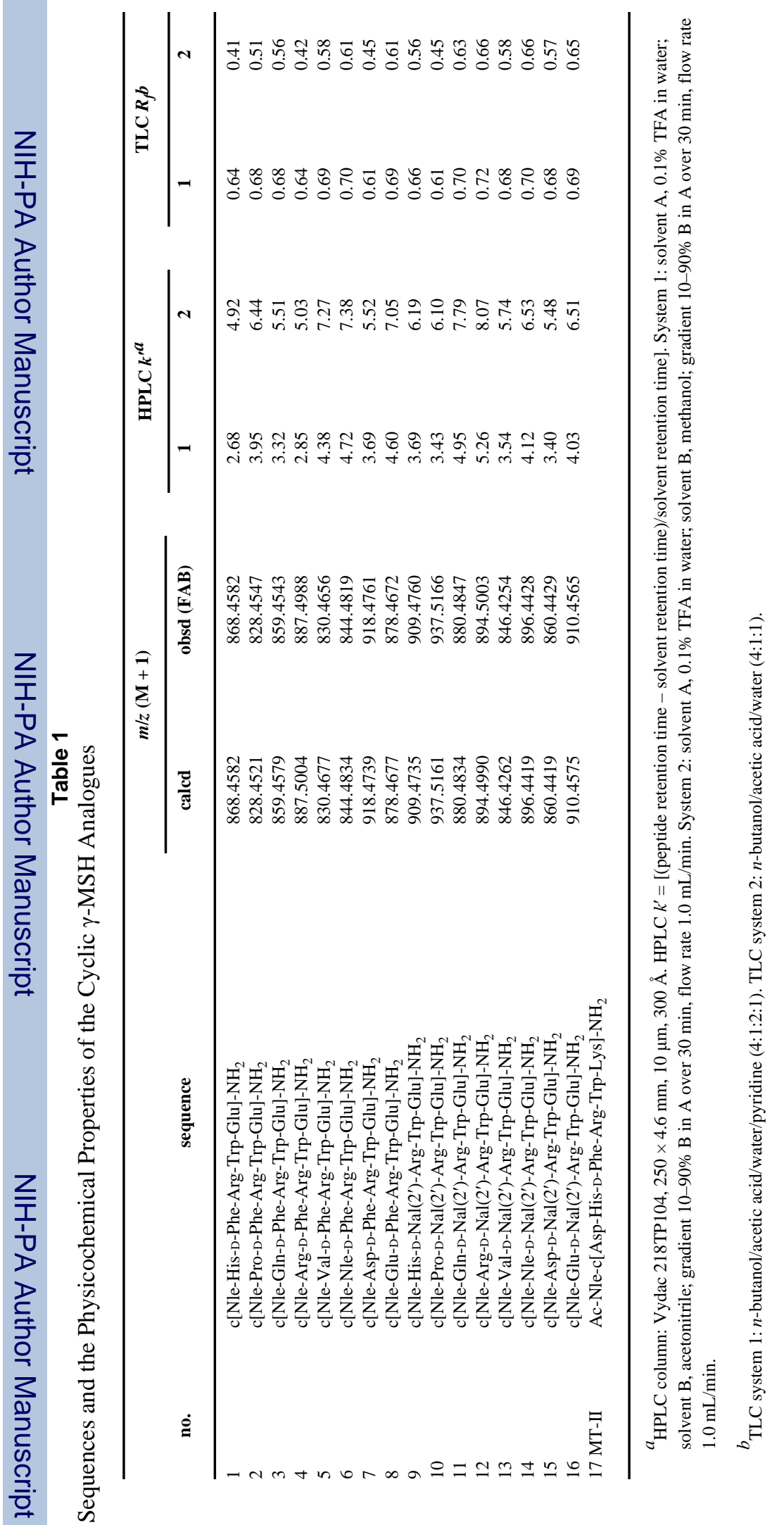




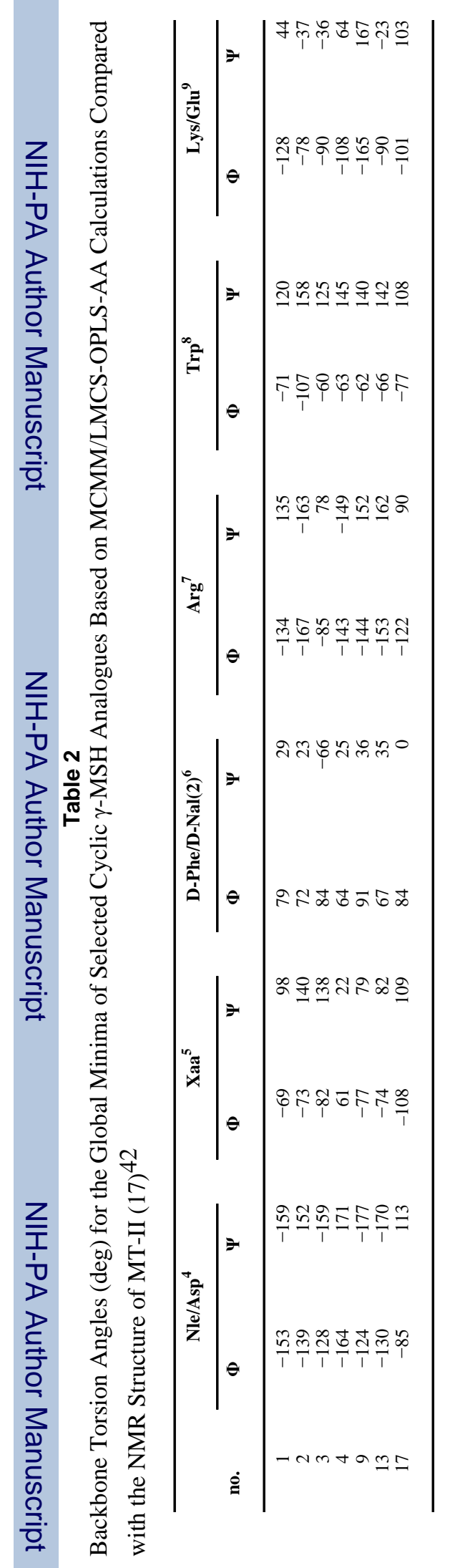

J Med Chem. Author manuscript; available in PMC 2006 June 30. 


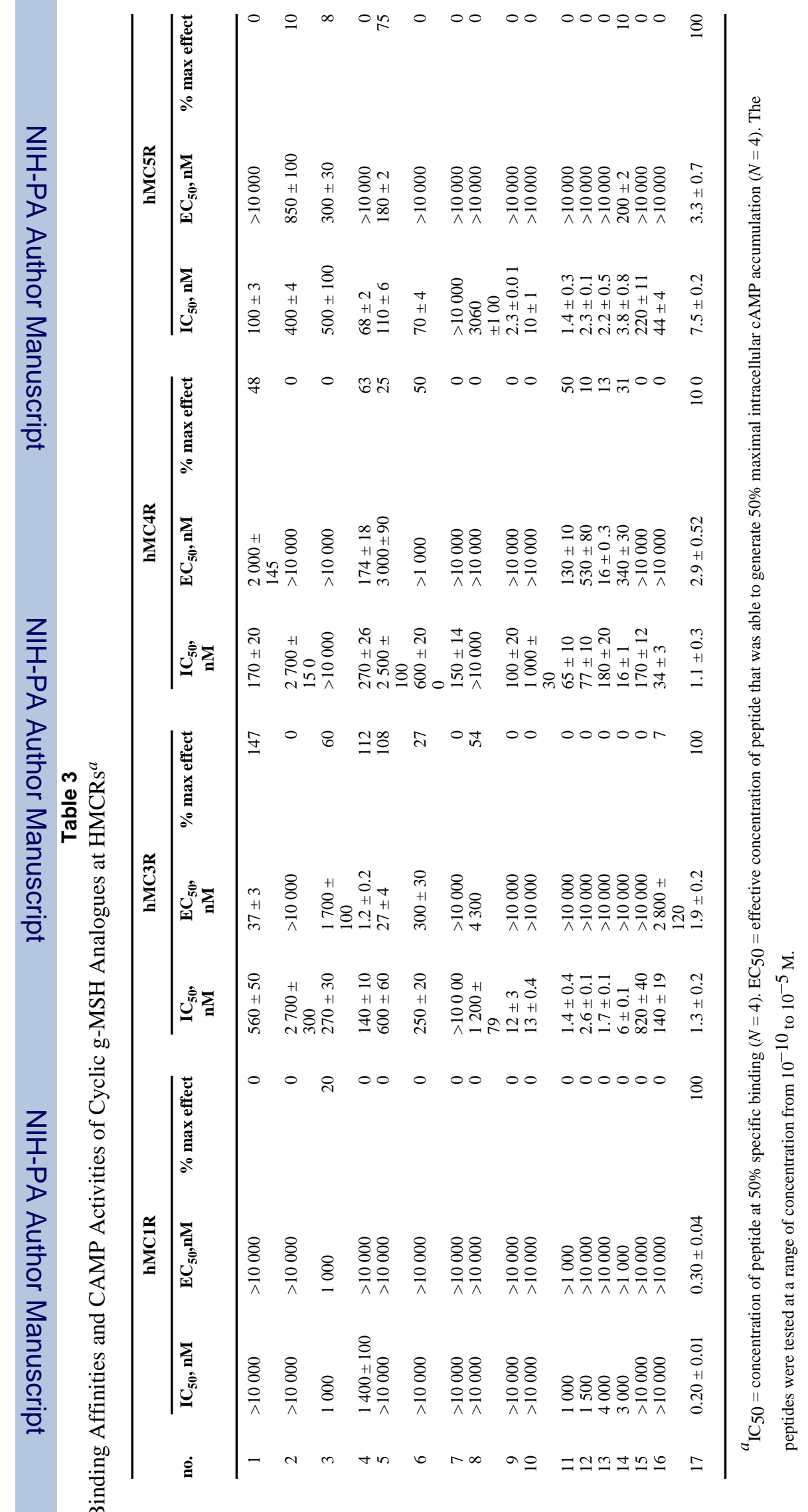

J Med Chem. Author manuscript; available in PMC 2006 June 30. 